TITLE:

\title{
Structural and immunostimulatory properties of Y-shaped DNA consisting of phosphodiester and phosphorothioate oligodeoxynucleotides.
}

\section{$\operatorname{AUTHOR}(\mathrm{S}):$}

Matsuoka, Nao; Nishikawa, Makiya; Mohri, Kohta; Rattanakiat, Sakulrat; Takakura, Yoshinobu

\section{CITATION:}

Matsuoka, Nao ... [et al]. Structural and immunostimulatory properties of Y-shaped DNA consisting of phosphodiester and phosphorothioate oligodeoxynucleotides.. Journal of controlled release 2010, 148(3): 311-316

\section{ISSUE DATE:}

2010-12-20

URL:

http://hdl.handle.net/2433/134574

\section{RIGHT:}

(c) 2010 Elsevier B.V.; この論文は出版社版でありません。引用の際には 出版社版をご確認ご利用ください。; This is not the published version. Please cite only the published version. 
Research Paper

Structural and immunostimulatory properties of Y-shaped DNA consisting of phosphodiester and phosphorothioate oligodeoxynucleotides

Nao Matsuoka, Makiya Nishikawa, Kohta Mohri, Sakulrat Rattanakiat and Yoshinobu

Takakura

Department of Biopharmaceutics and Drug Metabolism, Graduate School of

Pharmaceutical Sciences, Kyoto University, Sakyo-ku, Kyoto 606-8501, Japan

Corresponding author: Makiya Nishikawa, Department of Biopharmaceutics and Drug Metabolism, Graduate School of Pharmaceutical Sciences, Kyoto University, Sakyo-ku, Kyoto 606-8501, Japan. Telephone: +81-75-753-4580; Fax: +81-75-753-4614; E-mail: makiya@pharm.kyoto-u.ac.jp

\begin{abstract}
Y-shape formation increased the immunostimulatory activity of phosphodiester (PO) oligodeoxynucleotides (ODNs) containing CpG motif. In this study, PO CpG ODN or CpG ODN containing nuclease-resistant phosphorothioate (PS) linkages, i.e., PS CpG ODN or PO CpG ODN with three PS linkages at the both ends (PS3), was mixed with two PO- or PS ODNs to prepare Y-shaped DNA (Y-DNA) containing a potent CpG motif. The melting temperature of Y-DNA decreased with increasing number of PS linkages. Y(PS/PO/PO), which contained PS CpG ODN, showed the greatest activity to induce tumor necrosis factor- $\alpha$ release from macrophage-like RAW264.7 cells, followed by $\mathrm{Y}(\mathrm{PS} 3 / \mathrm{PO} / \mathrm{PO})$. However, the high activity of $\mathrm{Y}(\mathrm{PS} / \mathrm{PO} / \mathrm{PO})$ was due to that of PS CpG ODN, and Y-shape formation had no significant effect on the activity. Furthermore, PS CpG ODN of Y(PS/PO/PO) was efficiently taken up by cells, but other PO ODNs in the Y-DNA were not, indicating that PS CpG ODN in Y-DNA behave like single stranded PS CpG ODN. In quite contrast, the immunostimulatory activity of PS3 CpG ODN was significantly increased by Y-shape formation. In conclusion, Y-shape formation and PS substitution can be used simultaneously to increase the immunostimulatory activity of CpG ODN, but extensive substitution should be avoided because it diminishes the benefits of Y-shape formation.
\end{abstract}

Keywords: immunostimulatory DNA; phosphorothioate modification; nano-assembly; thermostability; macrophage; $\mathrm{CpG}$ motif 


\section{Introduction}

Enzymatic instability of natural phosphodiester (PO) DNA should be a result of natural selection. Recent studies on the biological and immunological properties of DNA have proved that DNA is an immunologically active compound when it is outside the nucleus. The mammalian immune system recognizes unmethylated $\mathrm{CpG}$ dinucleotides, or CpG motifs, as a signal of infection, through Toll-like receptor 9 (TLR9) expressed on dendritic cells, B cells and macrophages. ${ }^{1}$ Cells activated with CpG motif-containing DNA (CpG DNA) secrete a variety of cytokines, including tumor necrosis factor (TNF)- $\alpha$, interleukin (IL)-6 and IL-12, and also upregulate the expression of co-stimulatory molecules. ${ }^{2-4}$ Therefore, CpG DNA is expected to be used in the treatment of a wide range of diseases, including cancer, viral/bacterial infections, allergic diseases and inflammatory disorders. ${ }^{5,6}$

Despite potential use in treatments for a variety of diseases, therapeutic application of PO DNA generally requires its stabilization. In an attempt to stabilize enzyme-labile natural PO DNA, a variety of chemically modified DNAs have been developed. ${ }^{7}$ Of those modified analogues, phosphorothioate (PS) DNA is one of the most extensively used derivatives because of its easy production and high enzymatic stability. ${ }^{8-10}$ Vitravene, the first antisense drug marketed commercially, is a single stranded PS oligodeoxynucleotide (ODN) of 21 bases. ${ }^{11}$ PS modification increases not only enzymatic stability but also affinity of protein binding. The presence of diastereomer would also induce a variety of changes in the properties and activity of PS DNA.

We recently reported that building up CpG DNA into a Y-shaped form increases the immunostimulatory activity of CpG ODN; the Y-shaped DNA (Y-DNA) prepared using PO ODNs showed high potency to induce cytokines compared with single stranded (ssDNA) or double stranded DNA (dsDNA). ${ }^{12}$ Although the detailed mechanism of this structure-dependent enhancement has yet to be identified, these results indicate that the Y-shape formation can increase the potency of CpG ODN as an immunostimulatory agent. A variety of DNA preparations, including polyhedra, dendrimer-like DNA and DNA hydrogel, have been developed, ${ }^{13-16}$ but no attempts have been made to use nuclease-resistant DNA for the preparation of DNA structures with unique architecture. In the present study, the CpG Y-DNA, which consisted of three PO ODNs and contained a single highly potent $\mathrm{CpG}$ motif, ${ }^{12}$ was selected, and the PO linkages were substituted with PS linkages without any changes in the sequence. One of the three types of $\mathrm{CpG}$ ODN, i.e., PO ODN, PO ODN with three PS linkages at the both ends (PS3) and all PS ODN, was mixed with two PO- or PS ODNs to obtain Y-DNA. The Y-shape formation was first examined, followed by the evaluation of cytokine production, stability and cellular uptake after addition to TLR9-positive RAW264.7 cells.

\section{Materials and Methods}

\subsection{Chemicals}

RPMI1640 medium was obtained from Nissui Pharmaceutical Co., Ltd. (Tokyo, Japan). Fetal bovine serum (FBS) was obtained from Equitech-Bio, Inc (Kerrville, TX, USA). Opti-modified Eagle's medium (Opti-MEM) was purchased from Invitrogen (Carlsbad, CA, USA). The 20-bp DNA ladder was purchased from Takara Bio Inc. (Otsu, Japan). All other chemicals were of the highest grade available and used without further purification.

\subsection{Cell cultures}

Murine macrophage-like cells, RAW264.7, were grown in $5 \% \mathrm{CO}_{2}$ in humidified 
air at $37{ }^{\circ} \mathrm{C}$ with RPMI1640 medium supplemented with $10 \% \mathrm{FBS}, 100 \mathrm{IU} / \mathrm{ml}$ penicillin, $100 \mu \mathrm{g} / \mathrm{ml}$ streptomycin, and $2 \mathrm{mM}$ L-glutamine. Cells were plated on 24-well culture plates or 96 -well culture plates at a density of $5 \times 10^{5}$ cells $/ \mathrm{ml}$ and cultured for $24 \mathrm{~h}$ prior to use.

\subsection{Oligodeoxynucleotides}

All ODNs used were purchased from Integrated DNA Technologies, Inc. (Coralville, IA, USA). The sequences and internucleotide linkages of the ODNs are listed in Table 1. The three ODNs required for the $\mathrm{Y}$-DNA preparations were named as $\mathrm{Y}_{\mathrm{a}}$ (containing a highly potent $\mathrm{CpG}$ motif), $\mathrm{Y}_{\mathrm{b}}$ and $\mathrm{Y}_{\mathrm{c}}$. For cellular uptake studies, ODN ( $\mathrm{Y}_{\mathrm{a}}$ or $\mathrm{Y}_{\mathrm{b}}$ ) labeled with Alexa Fluor 488 at the 5'-end was purchased from JBioS (Saitama, Japan) and used to prepare fluorescently labeled DNA.

Table 1. The sequences of ODNs used for the preparation of ssDNA, dsDNA and Y-DNA.

\begin{tabular}{|c|c|}
\hline Name & Sequence $\left(5^{\prime} \rightarrow 3^{\prime}\right)$ \\
\hline $\mathrm{PO} \mathrm{Y_{ \textrm {a } }}$ & TGACGACGTTCGCATGACATTCGCCGTAAG \\
\hline $\mathrm{PO} \mathrm{Y}_{\mathrm{b}}$ & TGACCTTACGGCGAATGACCGAATCAGCCT \\
\hline $\mathrm{PO} \mathrm{Y_{c }}$ & TGACAGGCTGATTCGGTTCATGCGAACGTC \\
\hline PS3 $Y_{a}$ & $\mathrm{~T}^{*} \mathrm{G}^{*} \mathrm{~A} * \mathrm{CGACGTTCGCATGACATTCGCCGT} * \mathrm{~A} * \mathrm{~A} * \mathrm{G}$ \\
\hline PS $Y_{a}$ & 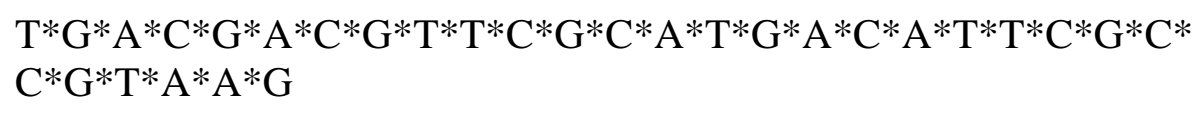 \\
\hline $\mathrm{PS} \mathrm{Y}_{\mathrm{b}}$ & 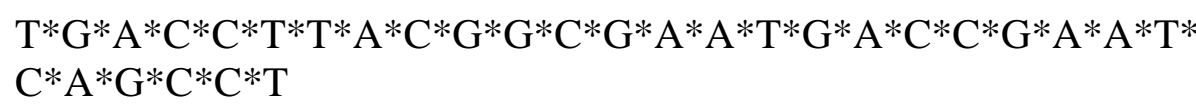 \\
\hline $\mathrm{PS} \mathrm{Y}_{\mathrm{c}}$ & $\begin{array}{l}T^{*} G^{*} A * C^{*} A^{*} G^{*} G^{*} C^{*} T^{*} G^{*} A^{*} T^{*} T^{*} C^{*} G^{*} G^{*} T^{*} T^{*} C^{*} A^{*} T^{*} G^{*} C^{*} G^{*} \\
A^{*} A * C^{*} G^{*} T^{*} C\end{array}$ \\
\hline an $\mathrm{PO} \mathrm{Y}_{\mathrm{a}}$ & TGACCTTACGGCGAATGTCATGCGAACGTC \\
\hline an PS $Y_{a}$ & 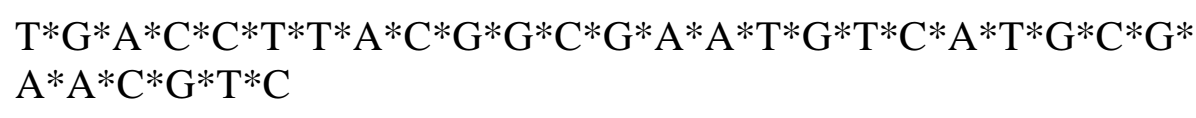 \\
\hline an $\mathrm{PO} \mathrm{Y}_{\mathrm{c}}$ & TGACGACGTTCGCATGAACCGAATCAGCCT \\
\hline
\end{tabular}

PS linkages are indicated by asterisks (*). The most potent immunostimulatory CpG motifs for rodents (GACGTT) are underlined. The "an" represents that the ODN is an antisense strand of $Y_{a}$ or $Y_{c}$, and would form dsDNA with 4-base overhangs at both 5'-ends.

\subsection{Preparation of $Y$-DNA and $d s D N A$}

Y-DNA was prepared by mixing equimolar amounts of $\mathrm{Y}_{\mathrm{a}}, \mathrm{Y}_{\mathrm{b}}$ and $\mathrm{Y}_{\mathrm{c}}$, as previously reported. ${ }^{12,14}$ Each Y-DNA preparation was named as $\mathrm{Y}(\mathrm{PO} / \mathrm{PO} / \mathrm{PO})$ and so on, with the letters in parenthesis representing the type of the internucleotide linkages of $\mathrm{Y}_{\mathrm{a}}, \mathrm{Y}_{\mathrm{b}}$ and $\mathrm{Y}_{\mathrm{c}}$ in this order. Three ODNs dissolved in TE buffer $(10 \mathrm{mM}$ Tris- $\mathrm{HCl}, 1 \mathrm{mM}$ ethylenediaminetetraacetic acid (EDTA), pH 8) containing $100 \mathrm{mM}$ sodium chloride were diluted with sterile Milli-Q water to a final concentration of $0.5 \mathrm{mM}$ for each ODN and $5 \mathrm{mM}$ for sodium chloride. Mixtures were then incubated at $95^{\circ} \mathrm{C}$ for $5 \mathrm{~min}, 65^{\circ} \mathrm{C}$ 
for $2 \mathrm{~min}, 62^{\circ} \mathrm{C}$ for $1 \mathrm{~min}$, and then slowly cooled to $4{ }^{\circ} \mathrm{C}$ using a thermal cycler. The products were analyzed by $12 \%$ polyacrylamide gel electrophoresis (PAGE) at room temperature (about $22-25^{\circ} \mathrm{C}$ ) or 4 ${ }^{\circ} \mathrm{C}$ at $200 \mathrm{~V}$ for $45 \mathrm{~min}$. dsDNA with 4-base overhangs at both 5'-ends was prepared using each $Y_{a}$ and its antisense strand with PO (an PO $\mathrm{Y}_{\mathrm{a}}$ ) or PS linkages (an PS $\mathrm{Y}_{\mathrm{a}}$ ). 2.5. Melting temperature of $Y-D N A$

The absorbance at $260 \mathrm{~nm}$ of Y-DNA was measured with a Shimadzu UV-1800 PC spectrometer (Kyoto, Japan) equipped with a TMSPC-8 temperature controller. DNA samples in TE buffer containing $5 \mathrm{mM}$ sodium chloride were gradually heated from 0 to $95^{\circ} \mathrm{C}$ at a constant rate of $1{ }^{\circ} \mathrm{C} / \mathrm{min}$. The thermal melting curves obtained were analyzed by the conventional two-point average method to obtain the melting temperature $(\mathrm{Tm})$.

\section{6. $T N F-\alpha$ release from $R A W 264.7$ cells} ssDNA (PO Y $\mathrm{a}_{\mathrm{a}}, \mathrm{PS} 3 \mathrm{Y}_{\mathrm{a}}$ or PS $\mathrm{Y}_{\mathrm{a}}$ ), dsDNA or Y-DNA diluted in $0.5 \mathrm{ml}$ Opti-MEM was added to RAW264.7 cells and incubated for $8 \mathrm{~h}$ at $37^{\circ} \mathrm{C}$. The dose was adjusted to about $70 \mathrm{nM}$, i.e., $0.67,1.33$ or 2 $\mu \mathrm{g} / \mathrm{ml}$ for ss-, ds- or Y-DNA, respectively. Then, the supernatants were collected and stored at $-70{ }^{\circ} \mathrm{C}$ until use. The levels of TNF- $\alpha$ in supernatants were determined by enzyme-linked immunosorbent assay (ELISA) using OptEIA ${ }^{\mathrm{TM}}$ sets (Pharmingen, San Diego, CA, USA).

\subsection{Stability of $Y$-DNA in serum}

Y-DNA $(10 \mu \mathrm{g} / 100 \mu \mathrm{l})$ was incubated with $70 \%$ mouse serum at $37{ }^{\circ} \mathrm{C}$. At $0,2,4$, 8,12 and $24 \mathrm{~h}$, a $10 \mu \mathrm{l}$ aliquot of the sample solution was transferred to plastic tubes and mixed with $20 \mu \mathrm{l} 0.5 \mathrm{M}$ EDTA solution to stop the degradation and then the mixtures were stored at $-20{ }^{\circ} \mathrm{C}$ until use. These samples were run on a $12 \%$ PAGE and stained with SYBR Gold (Molecular Probes, Eugene, OR, USA). The amounts of DNA in the gel were quantitatively evaluated by Multi Gauge (FUJIFILM, Tokyo, Japan).

2.8. Uptake of DNA in RAW264.7 cells

RAW264.7 cells on 96-well plates were incubated with Alexa Fluor 488-labeled (a)

(b)
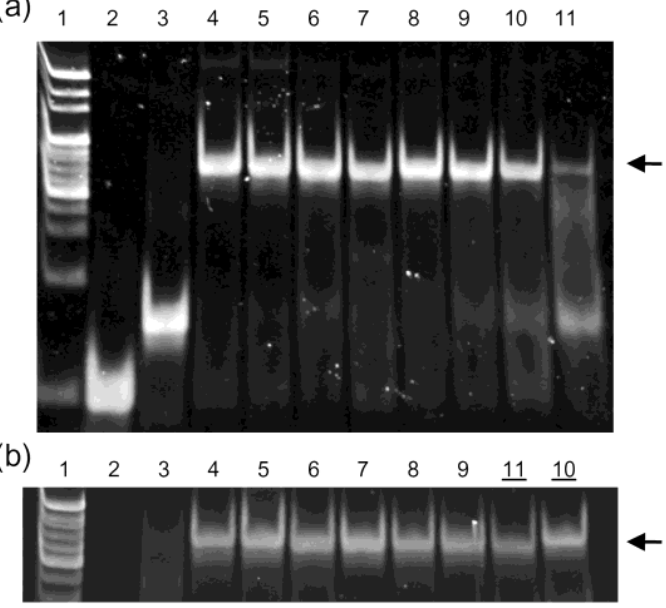

(c)

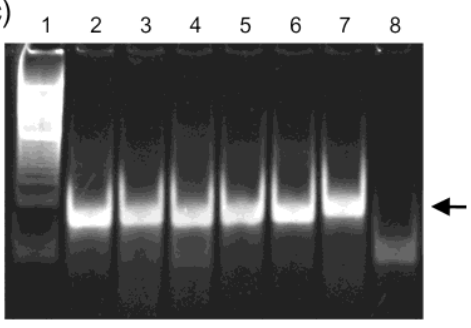

Fig. 1. PAGE analysis of single stranded (ss), double stranded (ds) and Y-DNA at $(\mathrm{a}, \mathrm{c})$ room temperature or

(b) $4{ }^{\circ} \mathrm{C}$. Each sample was run on a $12 \%$ polyacrylamide gel at $200 \mathrm{~V}$ for 45min. (a, b) Lane 1, 20-bp DNA ladder; lane 2, ssDNA (PO Y $\mathrm{b}$ ); lane 3, dsDNA ( $\mathrm{PO} \mathrm{Y}_{\mathrm{c}}$ /an $\mathrm{PO} \mathrm{Y}_{\mathrm{c}}$ ); lane 4, $\mathrm{Y}(\mathrm{PO} / \mathrm{PO} / \mathrm{PO})$; lane 5,

$\mathrm{Y}(\mathrm{PS} 3 / \mathrm{PO} / \mathrm{PO})$; lane 6, Y(PS/PO/PO); lane $7, \mathrm{Y}(\mathrm{PO} / \mathrm{PO} / \mathrm{PS})$; lane 8 , $\mathrm{Y}(\mathrm{PO} / \mathrm{PS} / \mathrm{PO})$; lane 9, Y(PS/PS/PO); lane 10, Y(PO/PS/PS); lane 11, $\mathrm{Y}(\mathrm{PS} / \mathrm{PS} / \mathrm{PS})$. (c) Lane 1, 20-bp DNA ladder; lane 2, dsDNA(PO $\mathrm{Y}_{\mathrm{a}} / \mathrm{an} \mathrm{PO}$ $\mathrm{Y}_{\mathrm{a}}$ ); lane 3, dsDNA(PO $\mathrm{Y}_{\mathrm{a}}$ /an PS $\mathrm{Y}_{\mathrm{a}}$ ); lane 4, dsDNA(PS3 $\mathrm{Y}_{\mathrm{a}}$ /an PO $\mathrm{Y}_{\mathrm{a}}$ ); lane 5, dsDNA(PS3 $\mathrm{Y}_{\mathrm{a}}$ /an PS $\mathrm{Y}_{\mathrm{a}}$ ); lane 6, dsDNA(PS $\mathrm{Y}_{\mathrm{a}}$ /an PO $\mathrm{Y}_{\mathrm{a}}$ ); lane 7, dsDNA(PS $\mathrm{Y}_{\mathrm{a}}$ /an PS $\mathrm{Y}_{\mathrm{a}}$ ); lane 8, $\operatorname{ssDNA}\left(\mathrm{PO} \mathrm{Y}_{\mathrm{a}}\right)$. 
ssDNA or Y-DNA at a concentration of 0.67 (ssDNA) or $2 \mu \mathrm{g} / \mathrm{ml}$ (Y-DNA). After 2 or 8 h-incubation at 37 or $4{ }^{\circ} \mathrm{C}$, cells were washed twice with $200 \mu$ phosphate buffered saline and harvested. Then, the fluorescent intensity of cells was analyzed by flow cytometry (FACS Calibur, BD Biosciences, NJ, USA) using CellQuest software (version 3.1, BD Biosciences). 2.9. Statistical analysis

Differences were statistically evaluated by one-way analysis of variance (ANOVA) followed by the Tukey-Kramer test for multiple comparisons. A $P$-value of $<0.05$ was considered to be statistically significant.

\section{Results}

\subsection{Formation of $Y-D N A$}

The formation of Y-DNA was evaluated by PAGE at room temperature (Fig.1a). A previous study demonstrated that Y-DNA, if successfully prepared, has a major single band with mobility less than that of ssDNA or dsDNA. ${ }^{12}$ A major band corresponding to the size of Y-DNA was detected for the Y-DNA preparations using at least one $\mathrm{PO}$ ODN (lanes 4-10), suggesting the formation of Y-DNA. On the other hand, Y(PS/PS/PS) showed only a faint band corresponding to Y-DNA (lane 11). When the PAGE analysis was performed at $4{ }^{\circ} \mathrm{C}$, not at room temperature, an efficient formation of Y(PS/PS/PS) was observed (Fig. 1b). Fig. 1c shows the PAGE analysis of dsDNA preparations at room temperature. All dsDNA, including dsDNA (PS $\mathrm{Y}_{\mathrm{a}}$ and an PS $\mathrm{Y}_{\mathrm{a}}$ ) (lane 7), were detected as double stranded.

\subsection{Tm of $Y-D N A$}

Fig. 2a shows the UV-melting temperature profiles of some Y-DNA preparations and the Tm values calculated. The $\mathrm{Tm}$ of $\mathrm{Y}(\mathrm{PO} / \mathrm{PO} / \mathrm{PO})$ was the highest $\left(44.1^{\circ} \mathrm{C}\right)$ among those examined, and the PS substitution at the both ends of $\mathrm{Y}_{\mathrm{a}}$ (Y(PS3/PO/PO)) slightly reduced the Tm to $43.2{ }^{\circ} \mathrm{C}$. However, the full substitution of $\mathrm{PO}$ linkages by $\mathrm{PS}$ in $\mathrm{Y}_{\mathrm{a}}, \mathrm{Y}_{\mathrm{b}}$ or $\mathrm{Y}_{\mathrm{c}}$ resulted in the reduction in the $\mathrm{Tm}$ to about $38^{\circ} \mathrm{C}(38.1$, (a)

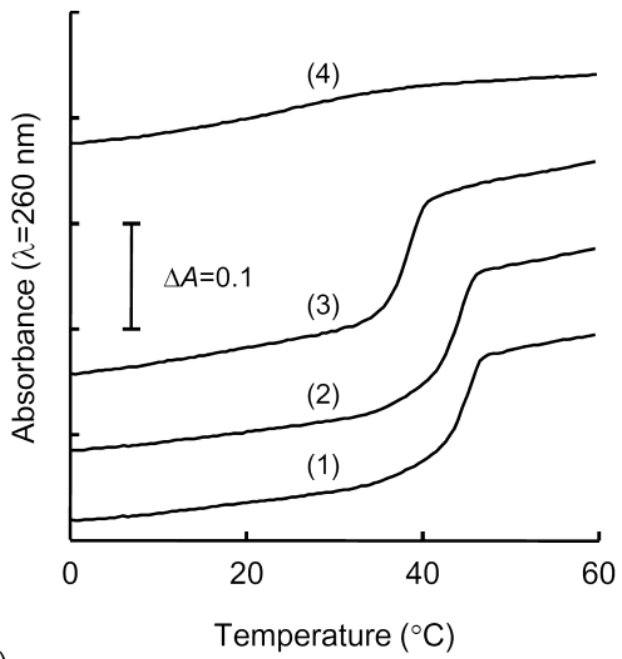

(b)

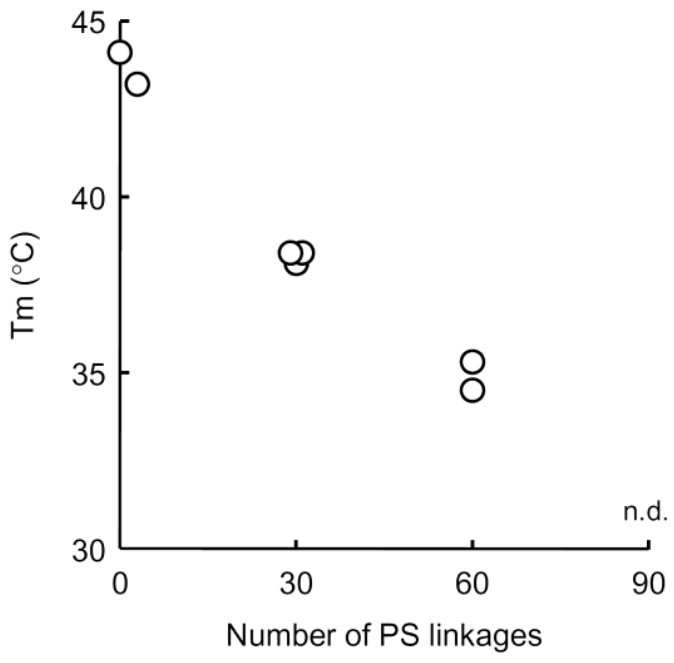

Fig. 2. Thermal stability of Y-DNA. (a) Thermal denaturation of Y-DNA was evaluated by measuring the absorbance at $260 \mathrm{~nm}$ with increasing temperature from 0 to $95^{\circ} \mathrm{C}$. The profiles from 0 to $60{ }^{\circ} \mathrm{C}$ were shown.

(1) $\mathrm{Y}(\mathrm{PO} / \mathrm{PO} / \mathrm{PO})$; (2) $\mathrm{Y}(\mathrm{PS} 3 / \mathrm{PO} / \mathrm{PO})$;

(3) $\mathrm{Y}(\mathrm{PS} / \mathrm{PO} / \mathrm{PO})$; (4) Y(PS/PS/PS).

(b) Tm calculated from the denaturation profile. Each Tm was plotted against the number of PS linkages in Y-DNA. The Tm of $\mathrm{Y}(\mathrm{PS} / \mathrm{PS} / \mathrm{PS})$ was not accurately determined because no significant shift in the absorbance was observed in the melting curve (Figure $2 \mathrm{a}(4)$ ). 
38.4 and 38.4 for $\mathrm{Y}(\mathrm{PS} / \mathrm{PO} / \mathrm{PO})$, $\mathrm{Y}(\mathrm{PO} / \mathrm{PS} / \mathrm{PO})$ and $\mathrm{Y}(\mathrm{PO} / \mathrm{PO} / \mathrm{PS})$, respectively), a $6{ }^{\circ} \mathrm{C}$ reduction. The preparations containing two PS ODNs showed a further lower Tm of 35.3 (Y(PS/PS/PO)) and $34.5^{\circ} \mathrm{C}(\mathrm{Y}(\mathrm{PO} / \mathrm{PS} / \mathrm{PS}))$. In the case of $\mathrm{Y}(\mathrm{PS} / \mathrm{PS} / \mathrm{PS})$, no significant shift in the absorbance was observed, so that its Tm was not properly calculated. The plot of Tm against the number of PS linkages in Y-DNA showed a decreasing trend (Fig. 2b).

\section{3. $T N F$ - $\alpha$ release from $R A W 264.7$ cells}

Fig. 3a shows the TNF- $\alpha$ concentration in the culture media of RAW264.7 cells after addition of Y-DNA. All Y-DNA preparation induced detectable TNF- $\alpha$ release, but the level was highly dependent on the linkages. $\mathrm{Y}(\mathrm{PO} / \mathrm{PO} / \mathrm{PO})$, which induced moderate TNF- $\alpha$ release in a previous study, ${ }^{12}$ was not so effective $(37.8 \pm 4.8 \mathrm{pg} / \mathrm{ml})$ at this low concentration of $2 \mu \mathrm{g} / \mathrm{ml}$. In contrast, $\mathrm{Y}(\mathrm{PS} 3 / \mathrm{PO} / \mathrm{PO})$ and $\mathrm{Y}(\mathrm{PS} / \mathrm{PO} / \mathrm{PO})$ induced TNF- $\alpha$ release up to $1,720 \pm 120$ and 6,170 $\pm 340 \mathrm{pg} / \mathrm{ml}$, respectively, suggesting that the PS modification of CpG ODN greatly increases its immunostimulatory activity even when built into Y-shape. The PS modification on $\mathrm{Y}_{\mathrm{b}}$ or $\mathrm{Y}_{\mathrm{c}}$ was not so effective in increasing the level of TNF- $\alpha$. $\mathrm{Y}(\mathrm{PO} / \mathrm{PO} / \mathrm{PS}), \mathrm{Y}(\mathrm{PO} / \mathrm{PS} / \mathrm{PO})$ and $\mathrm{Y}(\mathrm{PO} / \mathrm{PS} / \mathrm{PS})$ induced significantly less amounts of TNF- $\alpha$ than $\mathrm{Y}(\mathrm{PO} / \mathrm{PO} / \mathrm{PO})$. This PS ODN-dependent reduction in TNF- $\alpha$ release was much more apparent with PS CpG ODN; Y(PS/PS/PO), Y(PS/PO/PS) and $\mathrm{Y}(\mathrm{PS} / \mathrm{PS} / \mathrm{PS})$ induced $770 \mathrm{pg} / \mathrm{ml}$ or less $\mathrm{TNF}-\alpha$ release.

It was reported that double strand formation greatly reduced the immunostimulatory activity of PS CpG ODN. ${ }^{17}$ To examine how double strand- or Y-shape formation affects the immunostimulatory activity of CpG ODN, each type of $\mathrm{CpG}$ ODN was hybridized to a complementary PO- or PS ODN with 4-base overhang on 5'-ends, which was a similar structural character to Y-DNA. ssPO (PO Y $\mathrm{Y}_{\mathrm{a}}$ ), a single strand PO CpG ODN, induced a very low amount of TNF- $\alpha$ release when added to RAW264.7 cells at a concentration of
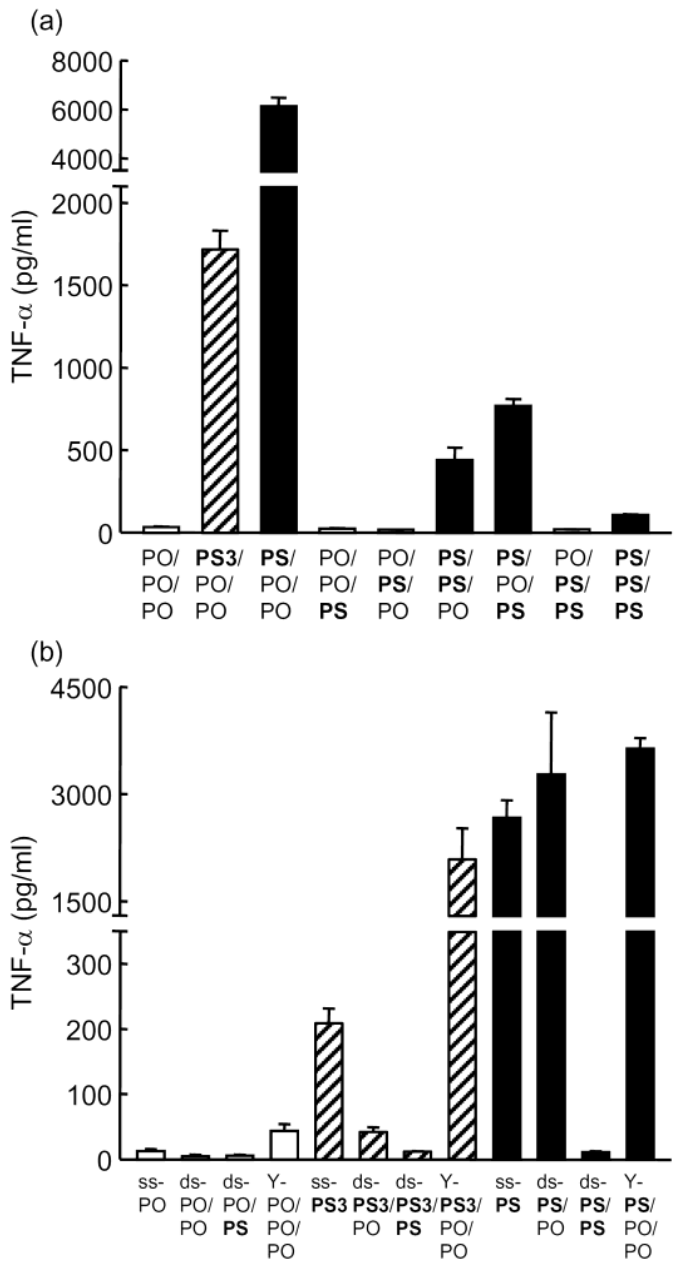

Fig. 3. TNF- $\alpha$ release from RAW264.7 cells by Y-DNA, ssDNA or dsDNA. (a) Cells were mixed with Y-DNA at a final concentration of 2 $\mu \mathrm{g} / \mathrm{ml}$, and the concentration of TNF- $\alpha$ in culture media was measured at $8 \mathrm{~h}$. (b) Cells were mixed with ssDNA $(0.67 \mu \mathrm{g} / \mathrm{ml})$, dsDNA $(1.3$ $\mu \mathrm{g} / \mathrm{ml})$ or Y-DNA $(2 \mu \mathrm{g} / \mathrm{ml})$, and the concentration of TNF- $\alpha$ in culture media was measured at $8 \mathrm{~h}$. Results are expressed as mean \pm SD of three determinations. (open bars) DNA with PO CpG ODN; (hatched bars) DNA with PS3 CpG ODN; (closed bars) DNA with PS CpG ODN. 
$0.67 \mu \mathrm{g} / \mathrm{ml}$, an identical concentration to the ODN added as Y-DNA at 2 $\mu \mathrm{g} / \mathrm{ml}$ (Fig. 3b). Double strand formation of ssPO with an PO $\mathrm{Y}_{\mathrm{a}}$ or an PS $\mathrm{Y}_{\mathrm{a}}$ further reduced the TNF- $\alpha$ release, even though the same amount of ssPO was added to cells (i.e., 1.3 $\mu \mathrm{g} / \mathrm{ml}$ for total DNA). As reported in the previous study, ${ }^{12}$ Y-shape formation increased the PO $\mathrm{CpG}$ ODN-mediated TNF- $\alpha$ release from cells. Similar, but more drastic, results were obtained with ssPS3, i.e., PS3 CpG ODN. Double strand formation of ssPS3 significantly reduced the TNF- $\alpha$ release, whereas Y-shape formation greatly increased the release up to almost 10-fold. On the other hand, double strand- or Y-shape formation of ssPS, PS-CpG ODN, had no significant effects on the TNF- $\alpha$ release, except for its double strand formation with PS ODN. These results suggest that the immunostimulatory activity of PO- or PS3 CpG ODN is significantly increased by Y-shape formation, but that of PS CpG ODN, which is highly immunostimulatory by itself, is not increased by Y-shape formation.

\subsection{Stability of $Y$-DNA in serum}

Based on the results thus far showing that PS linkages in the other strand than $\mathrm{CpG}$ ODN are not effective in increasing Y-DNA-mediated TNF- $\alpha$ release, $\mathrm{Y}(\mathrm{PO} / \mathrm{PO} / \mathrm{PO})$, $\mathrm{Y}(\mathrm{PS} 3 / \mathrm{PO} / \mathrm{PO})$ and $\mathrm{Y}(\mathrm{PS} / \mathrm{PO} / \mathrm{PO})$ were used for the subsequent experiments. To examine how the stability of DNA is involved in the immunostimulatory activity of Y-DNA, the degradation or decomposition of Y-DNA was investigated in mouse serum (Fig. 4a-c). Fig. 4d summarizes the time courses of the amount of remaining Y-DNA. The disappearance rate of $\mathrm{Y}(\mathrm{PS} / \mathrm{PO} / \mathrm{PO})$ was a little faster than that of other two, (a)

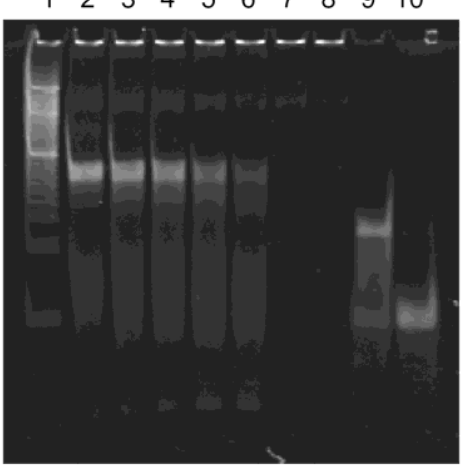

(c)

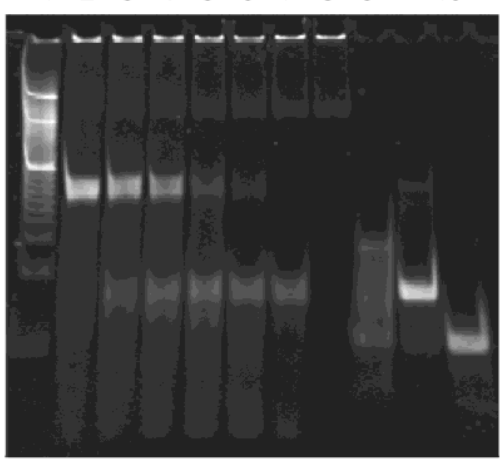

(d)

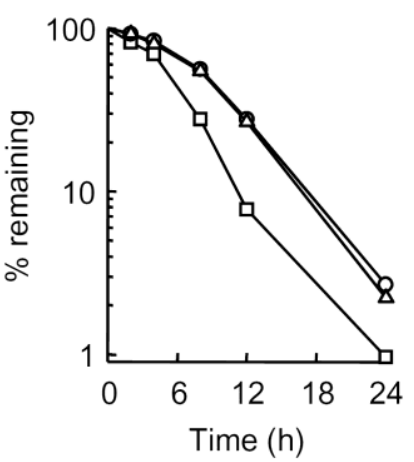

Fig. 4. Degradation of Y-DNA in mouse serum. (a-c) Y-DNA preparations were incubated in $70 \%$ mouse serum at $37{ }^{\circ} \mathrm{C}$ and the reaction was terminated by adding EDTA. The samples were run on $12 \%$ PAGE and stained with SYBR Gold. Lane 1, marker (20-bp DNA ladder); lane 2, $0 \mathrm{~h}$ (incubation time); lane 3, $2 \mathrm{~h}$; lane 4, $4 \mathrm{~h}$; lane 5, $8 \mathrm{~h}$; lane 6, $12 \mathrm{~h}$; lane 7, $24 \mathrm{~h}$; lane 8, mouse serum; lane 9, $\mathrm{PO} \mathrm{Y}_{\mathrm{a}}+\mathrm{PO} \mathrm{Y}_{\mathrm{b}}$; lane $10 \mathrm{PO} \mathrm{Y}_{\mathrm{a}}$ (ssDNA); lane *, PO $\mathrm{Y}_{\mathrm{a}}$ +an $\mathrm{PO} \mathrm{Y}_{\mathrm{a}}$. (a) $\mathrm{Y}(\mathrm{PO} / \mathrm{PO} / \mathrm{PO})$, (b) $\mathrm{Y}(\mathrm{PS} 3 / \mathrm{PO} / \mathrm{PO})$, (c) (PS/PO/PO). (d) The time course of the amount of remaining Y-DNA in the gel. $(\triangle)$ $\mathrm{Y}(\mathrm{PO} / \mathrm{PO} / \mathrm{PO})$; ( $)$ Y (PS3/PO/PO); ( $) \mathrm{Y}(\mathrm{PS} / \mathrm{PO} / \mathrm{PO})$. These experiments were performed three times with similar results and one representative gel is shown.

$\begin{array}{llllllllll}1 & 2 & 3 & 4 & 5 & 6 & 7 & 8 & 9 & 10\end{array}$

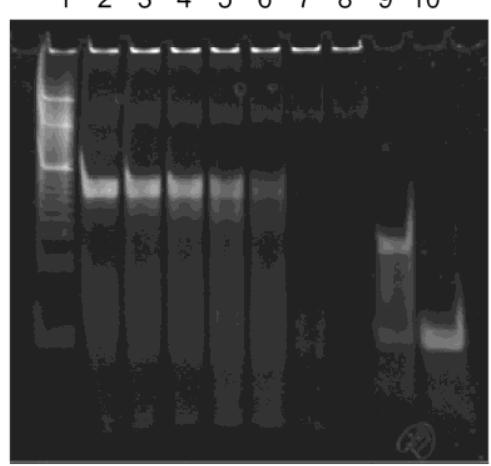


suggesting that PS modification somewhat reduced the stability of Y-DNA. However, an incubation of $\mathrm{Y}(\mathrm{PS} / \mathrm{PO} / \mathrm{PO})$ produced a new band with a faster migration than the Y-DNA. A PAGE analysis of two ODNs out of three for Y-DNA (PO $Y_{a}$ and $P O Y_{b}$ ) and dsDNA $\left(\mathrm{PO} \mathrm{Y}_{\mathrm{a}}\right.$ and an PO $\mathrm{Y}_{\mathrm{a}}$ ) showed that these two DNA preparations were separated on PAGE, even though both contained 40 bases in a unit. Two bands were detectable for the mixture of PO $Y_{a}$ and PO $Y_{b}$ (Fig. 4c, lane 9), one of which had a migration similar to that of ssDNA (PO Y $\mathrm{a}_{\mathrm{a}}$ lane 10). The new band detectable after incubation of $\mathrm{Y}(\mathrm{PS} / \mathrm{PO} / \mathrm{PO})$ in mouse serum had a migration distance similar to that of dsDNA (PO $\mathrm{Y}_{\mathrm{a}}$ and an PO $\mathrm{Y}_{\mathrm{a}}$ ) (Fig. 4c, lane *). This new band was detected at least for $24 \mathrm{~h}$. Taken together, these results suggest that the PO/PO double strand part of $\mathrm{Y}(\mathrm{PS} / \mathrm{PO} / \mathrm{PO})$ is quickly degraded, and the Y-DNA becomes dsDNA consisting of PS $\mathrm{Y}_{\mathrm{a}}$ and its complementary,

half-degraded two PO ODNs.

\subsection{Uptake of DNA in RAW264.7 cells}

To examine the uptake of $\mathrm{Y}_{\mathrm{a}}(\mathrm{CpG}$ ODN) and $Y_{b}$ (non-CpG ODN) separately, Y-DNA labeled with either ODN was added to RAW264.7 cells. In any case examined, the mean fluorescence intensity (MFI) of cells was significantly greater at $37^{\circ} \mathrm{C}$ than that at $4{ }^{\circ} \mathrm{C}$, indicating that DNA is internalized at the high temperature. Fig. 5a and $5 b$ show the MFI of cells after addition of Y-DNA labeled using either Alexa Fluor $488-Y_{a}$ or Alexa Fluor $488-Y_{b}$, respectively. The MFIs of $\mathrm{Y}(\mathrm{PO} / \mathrm{PO} / \mathrm{PO})$ at $8 \mathrm{~h}$ were 26.1 \pm 1.7 and $26.5 \pm 5.1$ when the uptake of $\mathrm{Y}(\mathrm{PO} / \mathrm{OP} / \mathrm{PO})$ was examined using Alexa Fluor $488-Y_{a}$ or Alexa Fluor $488-Y_{b}$, respectively, indicating that the labeling of different ODNs in $\mathrm{Y}(\mathrm{PO} / \mathrm{PO} / \mathrm{PO})$ had no significant effects on the measurement of cellular uptake. As reported in the previous study, ${ }^{12}$ the uptake of $\mathrm{Y}(\mathrm{PO} / \mathrm{PO} / \mathrm{PO})$ was greater than that of single strand $\mathrm{ODN}\left(\mathrm{Y}_{\mathrm{a}}\right.$, $\left.10.4 \pm 0.8 ; Y_{b}, 9.25 \pm 0.85\right)$. When the uptake was examined using Alexa Fluor 488- $Y_{b}$, a non-CpG ODN with PO linkages, the MFIs of Y(PS3/PO/PO) and Y(PS/PO/PO) were

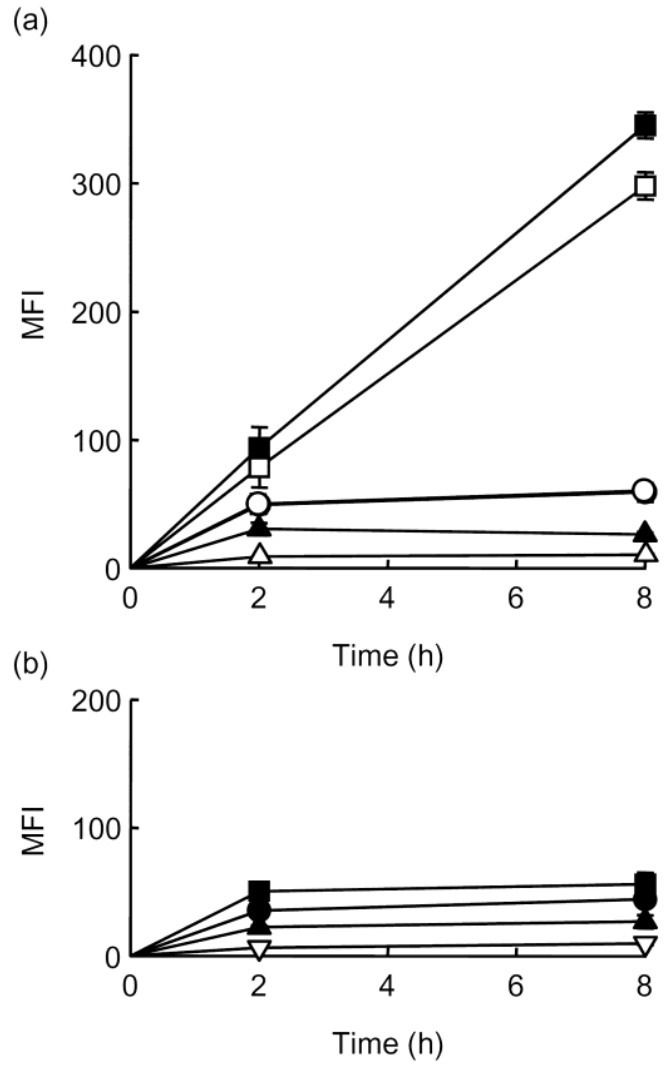

Fig. 5. Uptake of ssDNA or Y-DNA in RAW264.7 cells. RAW264.7 cells were incubated with Alexa Fluor 488-labelled ssDNA $(0.67 \mu \mathrm{g} / \mathrm{ml})$ or Y-DNA $(2 \mu \mathrm{g} / \mathrm{ml})$ for 2 or $8 \mathrm{~h}$ at 37 ${ }^{\circ} \mathrm{C}$. The amounts of DNA associated with cells were measured by flow cytometry. The mean fluorescence intensity of each Y-DNA was plotted against the incubation time. Results are expressed as the mean \pm SD of three determinations. (a) Alexa Fluor 488-labelled $\mathrm{Y}_{\mathrm{a}}\left(\mathrm{PO} \mathrm{Y}_{\mathrm{a}}, \mathrm{PS} 3 \mathrm{Y}_{\mathrm{a}}\right.$ or PS $Y_{a}$ ) was used for the labeling. (open symbols) ssDNA; (closed symbols) Y-DNA. $(\triangle, \boldsymbol{\Delta}) \mathrm{Y}(\mathrm{PO} / \mathrm{PO} / \mathrm{PO}) ;(\mathrm{O}$, •) $\mathrm{Y}(\mathrm{PS} 3 / \mathrm{PO} / \mathrm{PO})$; ( $\square$, ш) $\mathrm{Y}(\mathrm{PS} / \mathrm{PO} / \mathrm{PO})$. (b) Alexa Fluor 488-labelled $\mathrm{Y}_{\mathrm{b}}\left(\mathrm{PO} \mathrm{Y}_{\mathrm{b}}\right)$ was used for the labeling. $(\nabla)$ ssDNA $\left(\mathrm{PO} \mathrm{Y}_{\mathrm{b}}\right)$;

$$
\begin{aligned}
& \text { ( } \Delta \text { ) } \mathrm{Y}(\mathrm{PO} / \mathrm{PO} / \mathrm{PO}) ;(\bullet) \\
& \mathrm{Y}(\mathrm{PS} 3 / \mathrm{PO} / \mathrm{PO}) ;(\boldsymbol{\bullet}) \mathrm{Y}(\mathrm{PS} / \mathrm{PO} / \mathrm{PO}) \text {. }
\end{aligned}
$$


$43.9 \pm 1.1$ and $55.8 \pm 9.1$, respectively (Fig. $5 \mathrm{~b}$ ), which were significantly greater than that of $\mathrm{Y}(\mathrm{PO} / \mathrm{PO} / \mathrm{PO})$. In contrast, the MFIs of $\mathrm{Y}(\mathrm{PS} 3 / \mathrm{PO} / \mathrm{PO})$ and $\mathrm{Y}(\mathrm{PS} / \mathrm{PO} / \mathrm{PO})$ labeled using Alexa Fluor 488-Y $\mathrm{Y}_{\mathrm{a}}$, i.e., Alexa Fluor 488-PS3 CpG ODN or Alexa Fluor 488-PS CpG ODN, were 59.1 \pm 7.4 and $345 \pm 10$, respectively (Fig. 5a), which were much greater than those obtained using Alexa Fluor $488-Y_{b}$. These results suggest that $\mathrm{Y}(\mathrm{PS} / \mathrm{PO} / \mathrm{PO})$ is dissociated during the process of cellular uptake. The MFIs of single strand ODNs were 10.4 \pm 0.8, $60.4 \pm 2.6$ and $298 \pm 11$ for Alexa Fluor 488-ssPO, ssPS3 and ssPS, respectively.

\section{Discussion}

Short DNA-based drugs, such as antisense ODN, decoy ODN, aptamer and CpG ODN, have generally been developed using chemically stabilized DNA analogues, because natural PO DNA is too unstable for in vivo applications. PS DNA, a most frequently used stable DNA analogue, is known to have unique properties other than enzymatic stability that are different from PO DNA. One is high protein binding.18-20). We also found that PS substitution increased the binding of single strand ODN to RAW264.7 cells depending on the number of PS linkages (Fig. 5a). Another property is that PS DNA is a mixture of diastereomers due to phosphorus chirality. ${ }^{21}$ This leads to the instability of double strand formation with complementary strand, which can be assessed by Tm. ${ }^{22}$ PS ODN-mediated reduction in Tm was very clearly observed when such ODNs were used to form Y-DNA (Fig. 2). Therefore, it was demonstrated that PS modification increases the enzymatic stability of ODN but decreases the structural stability of Y-DNA. Three PS ODNs were not effective in being formed into a Y-shaped structure (Fig. 1), indicating that many PS linkages are not effective in constructing highly ordered DNA-based assemblies, even though simple dsDNA can be prepared using PS ODNs (Fig. 1c). The different effects of PS ODNs on the formation of Y-DNA and dsDNA would be due to the difference in the complementary sequences; the numbers of complementary sequences are 13 and 26 for Y-DNA and dsDNA, respectively. Experimental results on the degradation of Y-DNA in mouse serum showed a positive correlation between Tm and structural stability of Y-DNA, even though PS ODN and complementary PO ODNs seemed to be resistant to degradation (Fig. 4).

The immunostimulatory activity of ssCpG DNA was greatly increased by PS substitution at all or both ends (Fig. 3b). This high activity can be a result of two factors. One is the stabilization of ODN against enzymatic degradation, and the other is increased cellular uptake. We clearly demonstrated that the uptake of ssPS3 or ssPS by RAW264.7 cells was about 6- or 30-fold as large as that of ssPO, respectively (Fig. 5a). Because TLR9 localizes to endosomal compartments, CpG DNA is needed to be internalized to the intracellular compartments for the production of cytokines. High protein binding nature of PS linkages increases the binding of DNA to cells and subsequent internalization by endocytosis.

A great number of literatures reported that PS CpG ODNs are much more effective in inducing cytokines than PO ones upon addition to TLR9-positive cells. This high activity of PS CpG ODN can be explained by their high enzymatic stability and high cellular uptake. ${ }^{23}$ Even though ssPS was highly effective in inducing TNF- $\alpha$ and formed into Y-DNA with two PO ODNs, neither cellular uptake (Fig. 5a) nor immunostimulatory activity (Fig. 3b) of ssPS was increased by Y-shape formation. This was quite contrast to the results of ssPO. An interesting observation was that the uptake 
of Alexa Fluor 488-PS $\mathrm{Y}_{\mathrm{a}}$ was much greater than that of Alexa Fluor 488-PO $\mathrm{Y}_{\mathrm{b}}$ after addition of $\mathrm{Y}(\mathrm{PS} / \mathrm{PO} / \mathrm{PO})$ to RAW264.7 cells (Fig. 5). Such differences were not obvious for $\mathrm{Y}(\mathrm{PO} / \mathrm{PO} / \mathrm{PO})$ and $\mathrm{Y}(\mathrm{PS} 3 / \mathrm{PO} / \mathrm{PO})$. This would be explained as follows. Because of high affinity of PS ODN with cells, Y(PS/PO/PO) would bind to the surface of RAW264.7 cells via PS Y $\mathrm{a}_{\mathrm{a}}$ of the Y-DNA. Low structural stability of Y(PS/PO/PO) will facilitate the dissociation of PS $\mathrm{Y}_{\mathrm{a}}$ from the Y-DNA after addition to cells, especially when bound to cell surface. Then, the other two PO ODNs, including PO Y would be left unbound to cells. Almost complete inactivation of PS CpG ODN by double strand formation with PS ODN suggests that the CpG-TLR9 signaling is greatly inhibited by the double strand formation with PS ODN. This hypothesis was valid for all ODN preparations containing PS ODN as complementary ODNs to CpG ODN (Fig. 3). Therefore, PS substitution of CpG DNA is effective in increasing its immunostimulatory activity, but PS CpG ODN is not suitable as a building block of DNA assemblies, such as Y-DNA, X-DNA and dendrimer-like DNA. Furthermore, complementary PS ODNs to CpG DNA reduce its immunostimulatory activity, irrespective of the type of linkages of CpG DNA or of structure: dsDNA or Y-DNA. The detailed mechanism of this PS ODN-mediated reduction needs further investigations, but it was reported that PS CpG ODN had a higher affinity for TLR9 than PO CpG ODN, but a lower potential to activate cells ${ }^{24}$ and this could be involved in the inhibitory effects of PS ODNs.

Y-shape formation increased the immunostimulatory activity of ssPS3, a CpG ODN with three PS linkages at the both ends. The cellular uptake of ssPS3 was not affected by Y-shape formation, so that this increase seems to be dependent on the structure. Based on experimental data using Y-DNA and dendrimer-like DNA, ${ }^{12,25}$ we proposed a hypothesis that the branched structure is quite efficient in inducing the cytokine production by CpG DNA. This could be also applied to ssPS3, which is stabilized but behaves almost like ssPO, even though further studies are needed to elucidate underlying mechanisms. We found that the Tm of $\mathrm{Y}(\mathrm{PO} / \mathrm{PO} / \mathrm{PO})$ consisting of three 30 base ODNs (44.1 ${ }^{\circ} \mathrm{C}$; Fig. 2) was much lower than that of dsDNA consisting of PO $\mathrm{Y}_{\mathrm{a}}$ and an PO $\mathrm{Y}_{\mathrm{a}}$ (unpublished observation). Because it is reported that CpG ODN only acts as single strand, ${ }^{17}$ the low Tm value of Y-DNA could be suitable for the liberation of ssCpG ODN within endosomes and following interaction with TLR9.

\section{Conclusion}

We demonstrated that PS CpG ODN is a highly immunostimulatory compound that can induce cytokines, such as TNF- $\alpha$, upon addition to TLR9-positive cells. However, we also found that Y-DNA containing PS CpG ODN cannot act as Y-DNA, and no benefits are obtained by Y-shape formation. On the other hand, the immunostimulatory activity of PS3 CpG ODN is increased by Y-shape formation, indicating that partial substitution can be a choice for constructing highly immunostimulatory DNA assemblies, such as Y-DNA. As demonstrated in our previous studies, ${ }^{12,24}$ Y-DNA can be a building block of highly structured DNA assemblies, such as dendrimer-like DNA, and such assemblies are far effective as immunostimulatory compounds compared with ss-, ds- or Y-DNA. Therefore, we conclude here that PS substitution can be used in combination with Y-shape formation to increase the therapeutic potency of CpG DNA, but extensive substitution should be avoided because it decreases the structural stability of Y-DNA. 


\section{Acknowledgements}

This work was supported in part by a Health Labour Sciences Research Grant for Research on Advanced Medical Technology, from The Ministry of Health Labour and Welfare, Japan.

\section{References}

[1] H. Wagner, Toll meets bacterial CpG-DNA, Immunity 14 (2001) 499-502.

[2] D.M. Klinman, A.K. Yi, S.L. Beaucage, J. Conover, A.M. Krieg, CpG motifs present in bacteria DNA rapidly induce lymphocytes to secrete interleukin 6, interleukin 12, and interferon $\gamma$, Proc. Natl. Acad. Sci. USA 93 (1996) 2879-2883.

[3] T. Sparwasser, T. Miethke, G. Lipford, A. Erdmann, H. Häcker, K. Heeg, H. Wagner, Macrophages sense pathogens via DNA motifs: induction of tumor necrosis factor- $\alpha$-mediated shock, Eur. J. Immunol. 27 (1997) 1671-1679.

[4] S. Sun, X. Zhang, D.F. Tough, J. Sprent, Type I interferon-mediated stimulation of T cells by CpG DNA, J. Exp. Med. 188 (1998) 2335-2342.

[5] D.M. Klinman, Immunotherapeutic uses of CpG oligodeoxynucleotides, Nat. Rev. Immunol. 4 (2004) 249-258.

[6] A.M. Krieg, Therapeutic potential of Toll-like receptor 9 activation. Nat. Rev. Drug Discov. 5 (2006) 471-484.

[7] G.K. Mutwiri, A.K. Nichani, S. Babiuk, L.A. Babiuk, Strategies for enhancing the immunostimulatory effects of CpG oligodeoxynucleotides, J. Control. Release 97 (2004) 1-17.

[8] J.P. Shaw, K. Kent, J. Bird, J. Fishback, B. Froehler, Modified deoxyoligonucleotides stable to exonuclease degradation in serum, Nucleic Acids Res. 19 (1991) 747-750.

[9] H. Sands, L.J. Gorey-Feret, A.J. Cocuzza, F.W. Hobbs, D. Chidester, G.L. Trainor, Biodistribution and metabolism of internally ${ }^{3} \mathrm{H}$-labeled oligonucleotides. I. Comparison of a phosphodiester and a phosphorothioate, Mol. Pharmacol. 45 (1994) 932-943.

[10] Q. Zhao, D. Yu, S. Agrawal, Site of chemical modifications in CpG containing phosphorothioate oligodeoxynucleotide modulates its immunostimulatory activity, Bioorg. Med. Chem. Lett. 9 (1999) 3453-3458.

[11] R.S. Geary, S.P. Henry, L.R. Grillone, Fomivirsen: clinical pharmacology and potential drug interactions, Clin. Pharmacokinet. 41 (2002) 255-260.

[12] M. Nishikawa, M. Matono, S. Rattanakiat, N. Matsuoka, Y. Takakura, Enhanced immunostimulatory activity of oligodeoxynucleotides by Y-shape formation, Immunology 124 (2008) 247-255.

[13] N.C. Seeman, DNA engineering and its application to nanotechnology, Trends Biotechnol. 17 (1999) 437-443.

[14] Y. Li, Y.D. Tseng, S.Y. Kwon, L. D'Espaux, J.S. Bunch, P.L. Mceuen, D. Luo, Controlled assembly of dendrimer-like DNA, Nat. Mater. 3 (2004) 38-42.

[15] S.H. Um, J.B. Lee, N. Park, S.Y. Kwon, C.C. Umbach, D. Luo, Enzyme-catalysed assembly of DNA hydrogel, Nat. Mater. 5 (2006) 797-801.

[16] Y. He, T. Ye, M. Su, C. Zhang, A.E. Ribbe, W. Jiang, C. Mao, Hierarchical self-assembly of DNA into symmetric supramolecular polyhedral, Nature 452 (2008) 198-201.

[17] S. Zelenay, F. Elías, J. Fló, Immunostimulatory effects of plasmid DNA and synthetic oligodeoxynucleotides, Eur. J. Immunol. 33 (2003) 1382-1392. 
[18] D.A. Brown, S.H. Kang, S.M. Gryaznov, L. DeDionisio, O. Heidenreich, S. Sullivan, X. Xu, M.I. Nerenberg, Effect of phosphorothioate modification of oligodeoxynucleotides on specific protein binding, J. Biol. Chem. 269 (1994) 26801-26805.

[19] C.A. Stein, Exploiting the potential of antisense: beyond phosphorothioate oligodeoxynucleotides, Chem. Biol. 3 (1996) 319-323.

[20] J. Temsamani, A. Roskey, C. Chaix, S. Agrawal, In vivo metabolic profile of a phosphorothioate oligodeoxyribonucleotide, Antisense Nucleic Acid Drug Dev. 7 (1997) 159-165.

[21] A. Wilk, W.J. Stec, Analysis of oligo(deoxynucleoside phosphorothioate)s and their diastereomeric composition, Nucleic Acids Res. 23 (1995) 530-534.

[22] G. Rebowski, M. Wójcik, M. Boczkowska, E. Gendaszewska, M. Soszyński, G. Bartosz, W. Niewiarowski, Antisense hairpin loop oligonucleotides as inhibitors of expression of multidrug resistance-associated protein 1: their stability in fetal calf serum and human plasma, Acta Biochim. Pol. 48 (2001) 1061-1076.

[23] Kurreck J. Antisense technologies. Improvement through novel chemical modifications. Eur J Biochem. 270 (2003) 1628-1644.

[24] T. Haas, J. Metzger, F. Schmitz, A. Heit, T. Müller, E. Latz, H. Wagner, The DNA sugar backbone 2' deoxyribose determines toll-like receptor 9 activation, Immunity 28 (2008) 315-323.

[25] S. Rattanakiat, M. Nishikawa, H. Funabashi, D. Luo, Y. Takakura, The assembly of a short linear natural cytosine-phosphate-guanine DNA into dendritic structures and its effect on immunostimulatory activity, Biomaterials 30 (2009) 5701-5706.

\section{Figure legends}

Fig. 1. PAGE analysis of single stranded (ss), double stranded (ds) and Y-DNA at (a, c) room temperature or (b) $4{ }^{\circ} \mathrm{C}$. Each sample was run on a $12 \%$ polyacrylamide gel at $200 \mathrm{~V}$ for 45min. (a, b) Lane 1, 20-bp DNA ladder; lane 2, ssDNA (PO Y $\mathrm{b}_{\mathrm{b}}$ ); lane 3, dsDNA (PO Y $\mathrm{y}_{\mathrm{c}}$ an $\mathrm{PO} \mathrm{Y}_{\mathrm{c}}$ ); lane 4, Y(PO/PO/PO); lane 5, Y(PS3/PO/PO); lane 6, $\mathrm{Y}(\mathrm{PS} / \mathrm{PO} / \mathrm{PO})$; lane 7, Y(PO/PO/PS); lane 8, Y(PO/PS/PO); lane 9, Y(PS/PS/PO); lane 10, Y(PO/PS/PS); lane 11, Y(PS/PS/PS). (c) Lane 1, 20-bp DNA ladder; lane 2, dsDNA(PO $\mathrm{Y}_{\mathrm{a}} / \mathrm{an}$ PO $\mathrm{Y}_{\mathrm{a}}$ ); lane 3, dsDNA(PO $\mathrm{Y}_{\mathrm{a}} / \mathrm{an}$ PS $\mathrm{Y}_{\mathrm{a}}$ ); lane 4, dsDNA(PS3 $\mathrm{Y}_{\mathrm{a}} / \mathrm{an}$ PO $\mathrm{Y}_{\mathrm{a}}$ ); lane 5, dsDNA(PS3 $\mathrm{Y}_{\mathrm{a}}$ /an PS $\mathrm{Y}_{\mathrm{a}}$ ); lane 6, dsDNA(PS $\mathrm{Y}_{\mathrm{a}} / \mathrm{an}$ PO $\mathrm{Y}_{\mathrm{a}}$ ); lane 7, dsDNA(PS $Y_{a} / a n$ PS $\left.Y_{a}\right)$; lane 8, ssDNA $\left(P O Y_{a}\right)$.

Fig. 2. Thermal stability of Y-DNA. (a) Thermal denaturation of Y-DNA was evaluated by measuring the absorbance at $260 \mathrm{~nm}$ with increasing temperature from 0 to $95^{\circ} \mathrm{C}$. The profiles from 0 to $60{ }^{\circ} \mathrm{C}$ were shown. (1) Y(PO/PO/PO); (2) Y(PS3/PO/PO); (3) $\mathrm{Y}(\mathrm{PS} / \mathrm{PO} / \mathrm{PO})$; (4) Y(PS/PS/PS). (b) Tm calculated from the denaturation profile. Each Tm was plotted against the number of PS linkages in Y-DNA. The Tm of Y(PS/PS/PS) was not accurately determined because no significant shift in the absorbance was observed in the melting curve (Figure $2 \mathrm{a}(4)$ ).

Fig. 3. TNF- $\alpha$ release from RAW264.7 cells by Y-DNA, ssDNA or dsDNA. (a) Cells were mixed with Y-DNA at a final concentration of $2 \mu \mathrm{g} / \mathrm{ml}$, and the concentration of TNF- $\alpha$ in culture media was measured at $8 \mathrm{~h}$. (b) Cells were mixed with ssDNA $(0.67$ $\mu \mathrm{g} / \mathrm{ml})$, dsDNA $(1.3 \mu \mathrm{g} / \mathrm{ml})$ or Y-DNA $(2 \mu \mathrm{g} / \mathrm{ml})$, and the concentration of TNF- $\alpha$ in culture media was measured at $8 \mathrm{~h}$. Results are expressed as mean $\pm \mathrm{SD}$ of three 
determinations. (open bars) DNA with PO CpG ODN; (hatched bars) DNA with PS3 CpG ODN; (closed bars) DNA with PS CpG ODN.

Fig. 4. Degradation of Y-DNA in mouse serum. (a-c) Y-DNA preparations were incubated in $70 \%$ mouse serum at $37^{\circ} \mathrm{C}$ and the reaction was terminated by adding EDTA. The samples were run on $12 \%$ PAGE and stained with SYBR Gold. Lane 1, marker (20-bp DNA ladder); lane 2, 0 h (incubation time); lane 3, $2 \mathrm{~h}$; lane 4, $4 \mathrm{~h}$; lane 5, $8 \mathrm{~h}$; lane 6, $12 \mathrm{~h}$; lane 7, $24 \mathrm{~h}$; lane 8, mouse serum; lane 9, $\mathrm{PO} \mathrm{Y}_{\mathrm{a}}+\mathrm{PO} \mathrm{Y}_{\mathrm{b}}$; lane $10 \mathrm{PO}$

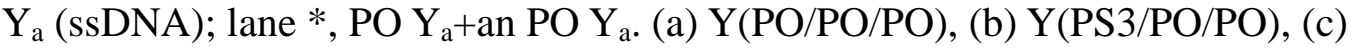
(PS/PO/PO). (d) The time course of the amount of remaining Y-DNA in the gel. $(\triangle)$ $\mathrm{Y}(\mathrm{PO} / \mathrm{PO} / \mathrm{PO})$; (०) Y(PS3/PO/PO); ( $)$ Y $\mathrm{Y}(\mathrm{PS} / \mathrm{PO} / \mathrm{PO})$. These experiments were performed three times with similar results and one representative gel is shown.

Fig. 5. Uptake of ssDNA or Y-DNA in RAW264.7 cells. RAW264.7 cells were incubated with Alexa Fluor 488-labelled ssDNA $(0.67 \mu \mathrm{g} / \mathrm{ml})$ or Y-DNA $(2 \mu \mathrm{g} / \mathrm{ml})$ for 2 or $8 \mathrm{~h}$ at $37^{\circ} \mathrm{C}$. The amounts of DNA associated with cells were measured by flow cytometry. The mean fluorescence intensity of each Y-DNA was plotted against the incubation time. Results are expressed as the mean \pm SD of three determinations. (a) Alexa Fluor 488-labelled $\mathrm{Y}_{\mathrm{a}}\left(\mathrm{PO} \mathrm{Y}_{\mathrm{a}}, \mathrm{PS} 3 \mathrm{Y}_{\mathrm{a}}\right.$ or PS $\mathrm{Y}_{\mathrm{a}}$ ) was used for the labeling. (open symbols) ssDNA; (closed symbols) Y-DNA. ( $\triangle, \boldsymbol{\Delta}) \mathrm{Y}(\mathrm{PO} / \mathrm{PO} / \mathrm{PO}) ;(\circ, \bullet)$ $\mathrm{Y}(\mathrm{PS} 3 / \mathrm{PO} / \mathrm{PO})$; $(\square, \boldsymbol{\square}) \mathrm{Y}(\mathrm{PS} / \mathrm{PO} / \mathrm{PO})$. (b) Alexa Fluor 488-labelled $\mathrm{Y}_{\mathrm{b}}\left(\mathrm{PO} \mathrm{Y}_{\mathrm{b}}\right)$ was used for the labeling. $(\nabla)$ ssDNA $\left(\mathrm{PO} \mathrm{Y}_{\mathrm{b}}\right) ;(\boldsymbol{\Delta}) \mathrm{Y}(\mathrm{PO} / \mathrm{PO} / \mathrm{PO}) ;(\bullet) \mathrm{Y}(\mathrm{PS} 3 / \mathrm{PO} / \mathrm{PO}) ;(\boldsymbol{\bullet})$ $\mathrm{Y}(\mathrm{PS} / \mathrm{PO} / \mathrm{PO})$. 